\title{
Oak growth, development and carbon metabolism in response to water stress
}

\author{
RE Dickson, PT Tomlinson \\ USDA Forest Service, North Central Forest Experiment Station, Forestry Sciences Laboratory, \\ 5985 Highway K, Rhinelander, WI 54501, USA
}

(Received 14 November 1994; accepted 19 June 1995)

\begin{abstract}
Summary - The genus Quercus (Fagaceae) contains both deciduous and evergreen species adapted to a wide range of sites differing widely in moisture availability. Different oak species have developed both morphological and physiological adaptations to survive and grow on such sites. Morphological adaptations in leaves, stems and roots aid in both drought avoidance and drought tolerance. Physiological adaptations involve control of stomatal conductance, leaf water potential, osmotic adjustment and photosynthetic carbon fixation. Carbon fixation can be divided into stomatal and nonstomatal responses. Stomatal response is probably the most important factor controlling carbon fixation. The more droughttolerant species control stomatal function to allow some carbon fixation with stress, thus improving water use efficiency, or open stomates rapidly when water stress is relieved. Nonstomatal responses of carbon fixation such as photosystem II light energy conversion and the dark reactions of Rubisco carbon fixation are quite resistant to water stress, although internal resistance to $\mathrm{CO}_{2}$ movement may increase. With water stress, soluble sugar/starch ratios increase, new leaf development decreases or stops altogether, and carbon allocated to leaf development shifts to lower stem and root for growth or storage. Many oak species, genotypes and hybrids are available that may be adapted to difficult sites. Use of such genotypes could greatly improve current forest management systems and horticultural amenity plantings.
\end{abstract}

Quercus / water-stress tolerance / photosynthesis / stomatal response / nonstomatal response / Rubisco / carbon allocation / genotypes / hybrids

Résumé - Croissance, développement et métabolisme du carbone de chênes soumis à une sécheresse. Le genre Quercus (Fagaceae) comporte à la fois des espèces décidues et des espèces sempervirentes adaptées à une large gamme de stations présentant des disponibilités en eau très diverses. Les chênes ont développé des adaptations morphologiques et physiologiques pour survivre et pousser dans ces stations. Des adaptations morphologiques dans les feuilles, les tiges et les racines permettent la fois la tolérance et l'évitement de la sécheresse. Les adaptations physiologiques impliquent à la fois le contrôle et la conductance stomatique du potentiel hydrique foliaire, du degré d'ajustement osmotique, et de la fixation photosynthétique de carbone. L'assimilation de carbone est contrôlée par des facteurs liés aux stomates ou d'origine non stomatique. La réponse des stomates est 
sans doute la plus importante réponse de limitation de la fixation photosynthétique de carbone. Les espèces les plus tolérantes à la sécheresse limitent la fermeture des stomates de manière à permettre une assimilation substantielle de carbone en situation de contrainte, ce qui leur permet d'améliorer leur efficience d'utilisation de l'eau; ou alors, elles les rouvrent très rapidement, dès que les réserves hydriques ont été reconstituées, même partiellement. Les processus non stomatiques de la photosynthèse, tels que la conversion photochimique et les réactions biochimiques des cycles de caboxylation centrés sur la Rubisco, semblent particulièrement peu sensibles à la sécheresse, même s'il s'avère que des résistances localisées dans le mésophylle et s'opposant à linflux de $\mathrm{CO}_{2}$ vers les chloroplastes puissent augmenter. Le rapport sucres solubles/amidon augmente en cours de sécheresse, l'expansion foliaire est ralentie, voire bloquée, et le carbone destiné initialement au développement des feuilles est détourné vers la base de la tige et vers les racines, où il sert à maintenir une croissance minimale, ou au stockage de réserves. De nombreux génotypes de chênes (espèces, hybrides, provenances) sont disponibles et peuvent s'adapter à des stations médiocres. L'utilisation de tels génotypes pourrait significativement améliorer la sylviculture du chêne et les plantations d'ornement.

\section{Quercus / tolérance à la sécheresse / photosynthèse / stomates / Rubisco / allocation de carbone /} génotypes / hybrides

\section{INTRODUCTION}

The genus Quercus in the family Fagaceae contains some of our most valuable forest tree species and some of our most persistent forest weed species. Oaks are native to most continents with about 500 species worldwide (Little, 1979; Kleinschmit, 1993; Rushton, 1993) (table I). The number of native species decreases from southern to northern latitudes (table I) consistent with the tropical origin of the species (Nixon, 1993). The genus contains both deciduous

Table I. Worldwide and regional distribution of native oak species (Quercus spp, Fagaceae).

No of species

$\begin{array}{lr}\text { Worldwide } & 500 \\ \text { North and South America } & 200 \\ \text { Mexico } & 125 \\ \text { United States } & 60 \\ \text { Europe } & 25 \\ \text { France } & 8 \\ \text { Wisconsin-Minnesota } & 7\end{array}$

Little, 1979; Kleinschmit, 1993; Rushton, 1993 and evergreen species adapted to a wide range of sites from seasonally flooded wetlands to xeric uplands and deep sands. Given this wide variation, it should be no surprise that response to water stress by individual species varies widely.

Because there have been several recent reviews about various aspects of plant response to water stress (Hsiao, 1973; Hinckley et al, 1978b, 1991; Kozlowski, 1982 a,b; Tyree and Ewers, 1991), we will confine this work largely to oaks, and if information is available, to individual species response to water stress. Special emphasis will be placed on the physiological sequences involved in carbon fixation, and carbon allocation in response to water stress. Species differences in response to water stress will be briefly reviewed to include recent comparisons of various American and European species not covered by Abrams (1990), and to provide background for the discussion of physiological responses. Similarly, morphological adaptations are briefly reviewed to emphasize characteristics of drought tolerance and drought avoidance and to provide additional background for physiological responses. Morphological and physiological adaptations must be considered together because both are involved to 
varying degrees in the strategies different oak species have developed to tolerate water stress.

\section{Species differences in response to water stress}

The adaptability of different oak species to water stress varies widely. A recent review by Abrams (1990) discusses the morphological and physiological adaptations of North American Quercus species in considerable detail.

Differences in rooting depth, leaf morphology, leaf water potential, osmotic potential, photosynthesis and stomatal conductance are involved in varying degrees in drought response. Both drought avoidance (deep rooting, leaf curling, leaf loss, etc) and drought tolerance (osmotic adjustment, stomatal control to maintain moderate photosynthetic rates, etc) are strategies used in varying degrees by different oak species (Pallardy and Rhoads, 1993). Nevertheless, because of the wide range of sites occupied by different oak species and the resulting extremes in moisture stress encoun- tered, there is no common oak strategy in response to water stress.

Different oak species may be placed in rather broad categories of moisture stress tolerance, based primarily on the sites they commonly occupy (table II, also see Wuenscher and Kozlowski, 1971; Hinckley et al, 1978a). Although most ecophysiological comparisons have been between oaks and other associated species (Abrams and Knapp, 1986; Kubiske and Abrams, 1993), some direct comparisons between different co-occurring oak species have been made. For example, black oak ( $Q$ velutina) had greater water use efficiency than bur oak $(Q$ macrocarpa), white oak ( $Q$ alba), and red oak ( $Q$ rubra) (Wuenscher and Kozlowski, 1971; Bahari et al, 1985), while chestnut oak ( $Q$ prinus) was more drought tolerant than red oak ( $Q$ rubra) (Abrams et al, 1990; Kleiner et al, 1992) (see Abrams 1990 and references therein for other direct comparisons). $Q$ rubra and $Q$ robur are quite sensitive to moisture stress and are found primarily on the best mesic to dry-mesic sites, although $Q$ rubra may be found on certain xeric sites (Kubiske and Abrams, 1992). $Q$ petraea is often associated with $Q$ robur in

Table II. Relative tolerance classification of Quercus species to water stress based on sites commonly occupied by the species.

Q rubra
$Q$ shumardii
$Q$ robur
$Q$ petraea
$Q$ velutina
$Q$ coccinea
$Q$ macrocarpa
$Q$ muehlenbergii
$Q$ marilandica
$Q$ stellata
$Q$ laevis
$Q$ gambelii

Northern red oak
Shumard oak
Pedunculate oak
Sessile oak
Black oak
Scarlet oak
Bur oak
Chinkapin oak
Blackjack oak
Post oak
Turkey oak
Gambel oak

Sensitive
Sensitive
Sensitive
Intermediate
Intermediate
Intermediate
Intermediate
Intermediate
Tolerant
Tolerant
Tolerant
Tolerant


forest stands, but $Q$ petraea is considered more drought tolerant (Levy et al, 1992; Breda et al, 1993). A direct comparison between $Q$ petraea, $Q$ robur and $Q$ rubra indicated that $Q$ petraea was more drought tolerant than the other two species (Vivin et al, 1993). $Q$ velutina, $Q$ coccinea and $Q$ macrocarpa are examples of species with intermediate to quite drought-tolerant characteristics. The upland variety of $Q$ macrocarpa is considered one of the most drought tolerant of the eastern North American oaks (Johnson, 1990). In the northwestern part of its range, $Q$ macrocarpa can grow in areas with less than $38 \mathrm{~cm}$ of rain per year. However, co-occurring $Q$ stellata and $Q$ muehlenbergii may be equally or more tolerant of water stress. In a competitive situation where both $Q$ macrocarpa and $Q$ muehlenbergii were growing on the same site, $Q$ muehlenbergii appeared more drought tolerant (Abrams and Knapp, 1986; Bragg et al, 1993). $Q$ marilandica and $Q$ stellata are common associates on nutrient-poor and droughty sites throughout the Missouri and Oklahoma Ozarks.

In eastern and central Oklahoma, these species form extensive low grade stands of "scrub oak". Other drought-tolerant species such as $Q$ laevis also are commonly found on nutrient-poor sites such as the sand hills and ridges of the southeastern United States (Berg and Hamrick, 1993). Quercus gambellii, found in the western and southwestern Unites States, is extremely modified morphologically to resist drought and fire. Over $50 \%$ of the plant biomass is commonly found underground in an extensive root system of rhizomes and lignotubers (Harrington, 1985; Clary and Tiedemann, 1986). In addition to large differences among species in drought tolerance, there are also large differences within species. Such genetic variation is commonly found in rangewide studies where western sources are more drought tolerant than eastern sources (Kriebel et al, 1976; Kuhns et al, 1993). Rainfall decreases from east to west in the United States. Genetic variation in drought tolerance may also be found within a species from a restricted geographic area. A study in central Pennsylvania showed that $Q$ rubra ecotypes from xeric sites had both physiological and morphological modifications that increased drought tolerance compared to ecotypes from mesic sites (Kubiske and Abrams, 1992). In a similar study, ridgetop trees of $Q$ ilex were more drought resistant than valley-bottom trees (Sala and Tenhunen, 1994).

\section{Morphological adaptations}

Leaves of different oak species have many morphological and anatomical characteristics that improve their ability to resist or tolerate moisture stress or drought episodes. Such features are not exclusive to oaks, but also are found in other species adapted to xeric sites and high light environments. Characteristics such as smaller leaf size, increased leaf thickness, increased cutical thickness, increased stomatal density and decreased stomatal size are all features that improve drought resistance, decrease leaf heat load and photochemical damage and help maintain some minimum rate of photosynthesis under water stress (Matsuda et al, 1989; Abrams, 1990; Abrams et al, 1994). In addition, the more drought-tolerant species often exhibit greater leaf anatomical plasticity (the ability to change anatomically in response to environmental stresses) than drought-intolerant species (Abrams and Kubiske, 1990; Ashton and Berlyn, 1994). Deep rooting also is an adaptation to resist site moisture stress by drought avoidance.

Oaks are commonly tap-rooted, and the more drought-tolerant species often produce greater root length per unit of leaf area than companion species (Pallardy and Rhoads, 1993). Oak tap roots, or sinker roots from lateral roots, commonly pene- 
trate 3 to $5 \mathrm{~m}$ in depth and may penetrate to $25 \mathrm{~m}$ or more (Stone and Kalisz, 1991). Taprooted or deep-rooted species may obtain most of their water requirements from the water table or deep groundwater sources and do not depend on uncertain rains and surface water (Ehleringer and Dawson, 1992). Predawn leaf water potential may be useful for estimating effective rooting depth. Both Hackberry (Celtis occidentalis $L$ ) and $Q$ muehlenbergiileaf water potential increased after a brief fall rain while $Q$ macrocarpa leaf water potential continued to decrease, indicating that $Q$ macrocarpa could not utilize rain water in the upper soil layers (Abrams and Knapp, 1986). The ability to increase root growth into and to increase root proliferation within enriched microsites is important for nutrient uptake (Eissenstat and Caldwell, 1988b; Black et al, 1994) and also may be a factor in drought tolerance (Fitter, 1986; Eissenstat and Caldwell 1988a). Wher tap-root growth was inhibited by dry soil, $Q$ agrifolia did not expand lateral roots into adjacent moist soil. In contrast, $Q$ lobata and $Q$ douglasii increased lateral root growth in the moist soil by 70 and $80 \%$, respectively (Callaway, 1990).

\section{CARBON FIXATION AND WATER STRESS}

Physiological responses to moisture stress associated with carbon fixation can be conveniently divided into stomatal and nonstomatal responses. Trees under moisture stress face the conflicting problem of maintaining some degree of photosynthesis while minimizing water loss. Stomatal control in response to varying moisture stress is the first and perhaps the most important step in this process. However, nonstomatal response, such as mesophyll resistance or photosynthetic mechanisms, also may be important aspects of stress tolerance (Kubiske and Abrams, 1993). The perceived relative importance of stomatal and nonstomatal response for control of photosynthetic carbon fixation has changed over the years as new evidence and new techniques have become available (Sharkey, 1990). The problem in determining control mechanisms lies in the fact that these are very complex systems, with many feedforward and feedback reactions, and with multiple control points that respond in different ways to environmental stress (Raschke, 1975; Chaves, 1991; Kelly and Latzko, 1991; Stitt and Schulze, 1994).

\section{Stomatal responses}

Stomatal closure decreases internal carbon dioxide concentration $\left(\mathrm{C}_{j}\right)$, which in turn alters photosynthetic mechanisms. These same photosynthetic mechanisms also may be independently influenced by water stress; therefore, it is very difficult to determine the exact sequence of events. Nevertheless, stomates do close with mild water stress, and this closure increases resistance to carbon dioxide diffusion into the leaf and water diffusion out of the leaf. Ideally, plants should maintain some level of internal $\mathrm{CO}_{2}$ concentration and carbon fixation and, at the same time, minimize water loss. Oaks are quite adept at this, particularly when compared to other associated tree species (Bahari et al, 1985; Kloeppel et al, 1993; Kubiske and Abrams, 1993). Differences in stomatal response, resistance to water stress and increased water-use efficiency also are found when xeric and mesic oak species are compared and when xeric and mesic ecotypes of the same species are compared (Kubiske and Abrams, 1992). In a study comparing ridge-top trees of $Q$ ilex to valley-bottom trees during a severe drought, the ridge-top trees regulated stomatal conductance to more closely match available soil moisture, maintained higher shoot water potential and suffered less 
severe moisture stress (Sala and Tenhunen, 1994).

The mechanisms that control stomatal opening and closing have been studied for many years (Raschke, 1975; Outlaw, 1983; Raschke et al, 1988). Many factors are involved such as $\mathrm{K}^{+}$movement, internal $\mathrm{CO}_{2}$ concentration, light intensity, cell water potential and hormones. Such studies are complicated because there are both shortterm (within minutes) and long-term (days to weeks) responses that probably have different control systems. In addition, there may well be multiple sensors for different environmental stresses. Here, we are concerned with the long-term effects of water stress on oak physiology. Response that takes place over days or weeks certainly requires exchange of information between shoots and roots, and such long-distance signaling usually requires a hormone (Gollan et al, 1989). Work in recent years has shown that abscisic acid (ABA) is probably the hormone involved (Davies and Zhang, 1991; Khalil and Grace, 1993; Davies et al, 1994), although other root-produced hormones and hormone precursors also may be involved (Smit et al, 1990; Jackson, 1994). Roots in drying soil respond to this local water stress by producing ABA. This root-produced $A B A$ is transported to leaves in the xylem sap where it decreases leaf expansion and stomatal conductance. Studies have shown that root production of $A B A$, xylem transport of $A B A$ and stomatal conductance are closely correlated without any measurable change in leaf water potential. For example, split root studies have shown that stomatal conductance responded to soil drying in one part of the root system with no effect on plant water status. Rewatering or severing the roots in drying soil restored stomatal conductance to well-watered conditions (Davies et al, 1994).

Trees also respond to other long-distance metabolic, hydraulic and perhaps electrical signals (Hewett and Wareing, 1973; Alvin et al, 1976; Mozes and Altman, 1977; Smit et al, 1990; Hinckley et al, 1991), but the relative importance of hormones or other potential signals to any particular species or particular environmental stress is unknown. Perhaps part of the advantage oaks have over other associated species is that they have better control of stomatal conductance, and thus carbon fixation by careful regulation of $\mathrm{ABA}$ or some other signal produced in the roots.

Stomatal and nonstomatal responses to water stress are usually defined by calculations of internal $\mathrm{CO}_{2}$ concentrations from gas exchange measurements (Farquhar and Sharkey, 1982; Jones, 1985). However, such calculations may introduce considerable error if stomatal closure is not uniform across the leaf. Patchy stomatal closure may lead to calculated decreases in photosynthesis, mean stomatal conductance, internal $\mathrm{CO}_{2}$ concentration, quantum yield and mesophyll conductance that may not be valid (Olsson and Leverenz, 1994). In addition, the degree of patchiness cannot be predicted because it varies with species, rate of drying and total imposed stress (Ni and Pallardy, 1992). Determinations of stomatal and nonstomatal responses require direct measurement of the various components of nonstomatal responses to differentiate the relative importance of these responses to stress (Epron and Dreyer, 1993a).

\section{Nonstomatal photosynthetic mechanisms}

Photosynthetic rates of $Q$ rubra rapidly decrease as water stress increases and often drop to zero under severe water stress (Weber and Gates, 1990). Such photosynthetic rates measured as carbon exchange rates do not provide much information about control mechanisms. Measurements of changes in stomatal conductance and pho- 
tosynthetic rates can divide photosynthetic response into stomatal and nonstomatal responses. Various nonstomatal responses, such as light energy reactions, mesophyll resistance to $\mathrm{CO}_{2}$ diffusion, Rubisco carbon fixation and other enzyme reactions, may be affected by water stress and decrease photosynthetic rates. Photosynthetic light response curves and $\mathrm{CO}_{2}$ response curves $\left(A / C_{i}\right.$ curves) can provide considerable information about the various physical and biochemical factors that control photosynthetic rates, such as quantum yield and other light energy reactions, and Rubisco activity or carboxylation efficiency. However, such response curves will not completely define the biochemical effects because many biochemical reactions are involved in photosynthesis control (Stitt, 1991; Stitt and Schulze, 1994).

Measurement of several metabolites and enzyme systems would be necessary to more completely define response controls. In addition, stomatal closure usually decreases internal $\mathrm{CO}_{2}$ concentration, which in turn influences both light energy reactions and photosynthetic biochemical reactions. Such physiological responses may result from either water stress or a decrease in internal $\mathrm{CO}_{2}$ concentration.

In recent years, several techniques applicable to field situations have become available for measuring both light energy reactions and photosynthetic mechanisms. With these techniques, such as in situ chlorophyll a fluorescence, net $\mathrm{CO}_{2}$ assimilation rates and stomatal conductances, considerable information on nonstomatal responses can be obtained. Studies with several oak species ( $Q$ rubra, $Q$ petraea, $Q$ pubescens, $Q$ cerris and $Q$ ilex) have shown that photosynthesis and stomatal conductance decreased rapidly with increasing water stress (Epron and Dreyer, 1990, 1993b; Epron et al, 1993). Carbon dioxide response curves $\left(A / C_{i}\right.$ response curves) indicated that both stomatal and nonstom- atal factors were involved in decreased carbon fixation. However, fluorescence measurements showed that light energy conversion, light-driven electron transport and ATP and nicotinamide adenine dinucleotide phosphate (NAPDH) production associated with photosystem II were not affected (Epron and Dreyer, 1990, 1993b; Epron et al, 1992, 1993). Similarly, the chemical production of ATP and NADPH was not affected by water stress in sunflower (Helianthus annuus) (Ortiz-Lopez et al, 1991).

Decreases in photosystem II (PS II) activity were found only with high light and severe drought conditions with no $\mathrm{CO}_{2}$ fixation. Such conditions can lead to damage in PS II reaction centers and photochemical bleaching when there is no outlet for the light energy and electron flow in the system (Epron et al, 1993). These studies showed that photochemistry and quantum yield remained stable with increasing water stress and thus could not explain the nonstomatal response indicated by analysis of the $A / C_{i}$ curves.

Nonstomatal response to water stress may not be associated with the mechanisms of light energy transfer or carbon fixation. Studies have shown that internal $\mathrm{CO}_{2}$ concentration may remain constant or actually increase as stomates close while PS II activity did not decrease (Epron and Dreyer, 1993a). Decreases in photosynthetic rates indicated that the internal resistance to $\mathrm{CO}_{2}$ movement (movement of $\mathrm{CO}_{2}$ from the stomatal cavity to the site of fixation in the chloroplast) increased (Epron and Dreyer, 1993a; Epron et al, 1995). Unfortunately, the amount and activity of Rubisco carbon fixation and other associated enzyme systems were not measured simultaneously. Additional studies with $Q$ petraea and ${ }^{14} \mathrm{C}$ autoradiography showed that this species responded to water stress with patchy stomatal closure and $\mathrm{CO}_{2}$ fixation. Thus, the nonstomatal response may be an artifact of the calculations involved from patchy stomatal 
closure and the decrease in photosynthetic carbon fixation was largely the result of stomatal closure (Epron and Dreyer 1993b).

Rubisco carbon fixation may or may not be directly affected by water stress. Although the evidence is conflicting, most studies indicate no significant water-stress effect on Rubisco activity (Gimenez et al, 1992). Studies that do show decreasing activity with water stress may not adequately evaluate other metabolites or metabolic activity that can indirectly influence Rubisco activity (Kicheva et al, 1994). In a recent study with tobacco plants transformed to contain different concentrations of functional Rubisco, the percentage decrease in photosynthesis with water stress was the same in all plants (Gunasekera and Berkowitz, 1993). In other words, the total amount of Rubisco activity available had no effect on the water stressinduced decrease in carbon fixation. Decreases in stomatal conductance and internal $\mathrm{CO}_{2}$ concentration were also similar among the transformed plants, and internal $\mathrm{CO}_{2}$ concentration remained well above the compensation point. If Rubisco activity decreased with water stress, steady-state concentrations of ribulose-1,5-bisphosphate (RuBP) should increase, barring changes in other enzyme systems. Instead, concentrations of RuBP decreased with increasing water stress, indicating a water-stress effect on the enzymatic regeneration of RuBP, which in turn inhibited Rubisco carbon fixation. Other enzyme systems, such as sucrose phosphate synthase and nitrate reductase, decrease in activity with water stress (Sharkey, 1990; Stitt and Schulze, 1994). However, such decreases in enzyme activity are probably the result of low internal $\mathrm{CO}_{2}$ concentration in water-stressed plants because activity recovers if these water-stressed plants are placed in high $\mathrm{CO}_{2}$.

Determining which enzyme system and control functions change with water stress will require carefully designed studies that examine several such functional systems at the same time. Stomatal and nonstomatal effects of water stress vary with species, rate and degree of water stress imposed, and with many other factors. However, carefully designed studies that examine several such aspects have already clarified differences in drought response among oak species, such as $Q$ rubra, $Q$ petraea and $Q$ cerris that potentially differ widely in drought tolerance (Epron et al, 1993).

\section{CARBON ALLOCATION AND WATER STRESS}

\section{Water stress and leaf development}

Leaf development is probably the most sensitive plant response to water stress. Leaf expansion rates decrease in response to soil moisture stress well before measurable effects on shoot-water relations are found (Davies and Zhang, 1991; Davies et al, 1994). In addition, leaf expansion decreases well before root growth decreases with water stress (Ball et al, 1994). As with stomatal conductance, some long-distance signal from roots decreases leaf growth, thus maintaining a balance between shoot and root growth and permitting a shift of carbon allocation to roots for continual growth. The mechanisms that control leaf expansion in response to changing plant water status are not clear, and the interactions between roots and leaf cell turgor change are largely unknown (Borchert, 1991), but may involve transmission of pressure changes, electrical, or hormonal signals (Daie, 1988; Smit et al, 1990).

Leaf development is particularly important to flushing species such as oak because the total leaf area of the expanding flush is critical for cumulative carbon fixation. Indeterminate species may continue production of smaller leaves under mild water stress 
(Metcalfe et al, 1989) while flushing may be completely stopped in oak. The control of episodic growth flushes in oak is unknown (Dickson, 1994), but oaks have a conservative growth strategy in which flushing and new leaf production cease or are severely depressed with various environmental stresses and photosynthate is redirected to root growth and storage (Gordon et al, 1989; Dickson, 1991b). Water stress in oak and other flushing species decreases the rate of leaf expansion, decreases final leaf size and decreases the number of leaves in a flush (Gordon et al, 1989). Severe soil moisture stress is not required to significantly decrease leaf area and dry weight of northern red oak seedlings (table III). Similar results were found for cacao (Theobroma cacao $\mathrm{L}$ ), a flushing species like oak, where an increase in water stress caused a rapid decrease in leaf expansion of the develop. ing flush and redirection of photoassimilate from the developing flush to lower stem and roots (Deng et al, 1990). The decrease in total leaf area, associated with decreases in stomatal conductance and photosynthesis, significantly decreases total carbon fixation.

\section{Water stress and carbon partitioning within the leaf}

Carbon partitioning to different chemical fractions within the leaf is the result of a number of alternative enzyme reactions, cofactors and interacting control points all dependent in turn on genotype, developmental stage of the plant and environmental factors (Daie, 1988; Stitt and Quick, 1989; Stitt and Schulze, 1994). Thus, it is not surprising that carbon partitioning is influenced by water stress. A common response to water stress is a shift in carbon flow to sucrose and other low molecular weight compounds. Such shifts aid in the maintenance of turgor and increase transportable
Table III. Effect of drought stress timing on leaf growth of northern red oak seedlings.

$\begin{array}{lcc}\begin{array}{l}\text { Timing of } \\ \text { stress }\end{array} & \begin{array}{c}\text { Leaf area } \\ \left(\mathrm{cm}^{2}\right)\end{array} & \text { Leaf dry weight } \\ & (\mathrm{g})\end{array}$

$\begin{array}{lll}\text { Flush }^{2} & & \\ \text { Control } 1 & 807^{\mathrm{a}} 2 & 4.50^{\mathrm{a}} \\ \text { Early } & 101^{\mathrm{c}} & 0.55^{\mathrm{c}} \\ \text { Mid } & 345^{\mathrm{b}} & 1.83^{\mathrm{b}} \\ \text { Late } & 497^{\mathrm{b}} & 2.83^{\mathrm{b}}\end{array}$

$\begin{array}{lrl}\text { Flush } & & \\ \text { Control } & 1402 \mathrm{a} & 7.06 \mathrm{a} \\ \text { Early } & 237 \mathrm{~b} & 1.12^{\mathrm{b}} \\ \text { Mid } & 412^{\mathrm{b}} & 1.64 \mathrm{~b} \\ \text { Late } & 579^{\mathrm{b}} & 3.10^{\mathrm{b}}\end{array}$

1 Control plants were well watered throughout the experiment and experienced no water stress. The early, mid and late treatments were water-stress cycles started at acorn planting, after 2 and 4 weeks, respectively. These treatments produced 3,2 , and 1 dry-down cycles by the time plants reached 3 lag and were harvested (see Dickson, $1991 \mathrm{~b}$ for explanation of the Quercus morphological index [QMl] system). The plants were rewatered after the soil reached $12 \%$ soil moisture as measured with time domain reflectrometry (TDR). At $12 \%$ moisture content, plant water potential increased to about -1.0 to $-1.2 \mathrm{MPa} .{ }^{2}$ Data are the mean of at least five replicates. Letters indicate significant differences $(P=0.01)$ as determined with Duncan's multiple range test.

compounds (Morgan, 1984; Chaves, 1991). The sucrose/starch ratio usually increases with water stress as a result of increased flow of carbon to sucrose and, in some cases, an increase in starch breakdown. A shift from starch storage to sucrose has adaptive value because it enables osmotic adjustment and sustains export during stress events. The exact mechanism(s) of the shift in sucrose production is unknown. Starch is often considered a storage or "overflow" carbohydrate pool for excess carbon fixed during periods of high photosynthetic rates. In contrast, it is more likely that starch and sucrose production are independently controlled to provide an integrated response to 
changing environmental conditions (see Daie, 1988 and references therein). In addition, starch is synthesized in the chloroplast and sucrose is synthesized in the cytosol, and their relative rates of synthesis are controlled by a number of transmembrane carriers and enzyme systems (Dickson, 1991a). These systems are adaptive; adjusting to different environmental requirements; and they also are interactive, responding to changing requirements of the whole plant. These multiple enzyme systems and alternative pathways for carbon flow provide redundancy so that the plant can adapt to changing environmental conditions.

Most of the information given here on carbon partitioning was developed with research on crop plants such as sugar beat and soybean because of their agricultural importance, genetic uniformity and growth uniformity. However, much information is available from work on hardwoods and conifers (Dickson, 1991a; Gower et al, 1995), and more could be developed for oaks grown with various environmental stresses. Because oaks are flushing species with cyclic leaf development, it is very important to use a developmental index such as the Quercus morphological index (QMI) (Dickson, 1991b) to study plants at the same developmental stage. Current studies on $Q$ rubra indicate that the major carbon metabolic pathways in leaves do not differ from those described for other plants (Dickson et al, 1990).

\section{Water stress and carbon allocation within the plants}

A common short-term response to water stress is the retention of current photosynthate in source leaves (Kuhns and Gjerstad, 1988; Deng et al, 1990). Water-stressed (leaf water potential $-1.8 \mathrm{MPa}$ ) cacao seedlings retained $86 \%$ of photosynthetically fixed ${ }^{14} \mathrm{C}$ in source leaves $72 \mathrm{~h}$ after labeling, compared to $14 \%$ for nonstressed seedlings
(Deng et al, 1990). This retention of sucrose or other low molecular weight compounds in source leaves may be caused by a shift from export pools to vacuole storage and other leaf pools. Export processes are probably not the cause of the retention of recently fixed carbon because export capacity or translocation processes are relatively insensitive to water stress (Daie, 1988). Although the total amount of recently fixed carbon available for export usually declines because of decreases in carbon fixation or shifts in carbon pools, starch hydrolysis and efficiency of sucrose loading into the phloem may increase to maintain transport

Long-term control of carbon allocation within the plant is regulated by source-sink interactions. The major sources in vegetative plants are mature leaves. The major sinks in vegetative plants are young developing leaves and stems, growing roots and stem and root storage pools (Dickson, 1991a). Under normal conditions or mild water stress, source leaves fix enough carbon for their own maintenance and for export to different sinks. Allocation of carbon to different sinks is largely independent of assimilate production, but is related to sink strength. Sink strength is related to size, growth rate, metabolic activity and respiration rate (Farrar et al, 1993). Developing leaves are strong sinks; stem and root storage pools are weak sinks in actively growing plants (Chapin et al, 1990). Perennial plants have developed elaborate sensing and control systems designed to maximize growth and to minimize damage in response to environmental stresses. Control of leaf expansion is one such system. As water stress increases, leaf expansion rates decrease (Joly and Hahn, 1989). When developing leaf growth slows, the relative sink strength decreases and more assimilate is available for transport to lower stem and roots. An increase in root growth or a decrease in shoot/root ratio is a common response to water stress. In a study with alfalfa (Med- 
icago sativa $\mathrm{L}$ ), mild water stress decreased leaf growth but increased root dry weight (Hall et al, 1988). Roots of stressed plants contained twice as much translocated ${ }^{14} \mathrm{C}$, and starch content increased by 20 to $30 \%$ compared to control plants. Oaks have a semideterminate growth habit with episodic flushes of new leaf and stem growth. Because all of the leaves are expanding at the same time, the new flush is a major sink for photosynthate. Our studies have shown that over $90 \%$ of the photosynthate from first-flush leaves was allocated to this new shoot growth (Isebrands et al, 1994). After leaf expansion, $95 \%$ of the current photosynthate was allocated to the lower stem and root for growth and storage (fig 1). Any change in this flushing growth pattern that decreases leaf growth or stops flushing would increase carbon allocation downward to the root system.

\section{SILVICULTURAL AND ECOLOGICAL CONSIDERATIONS}

Given the considerable amount of information available concerning biological attributes

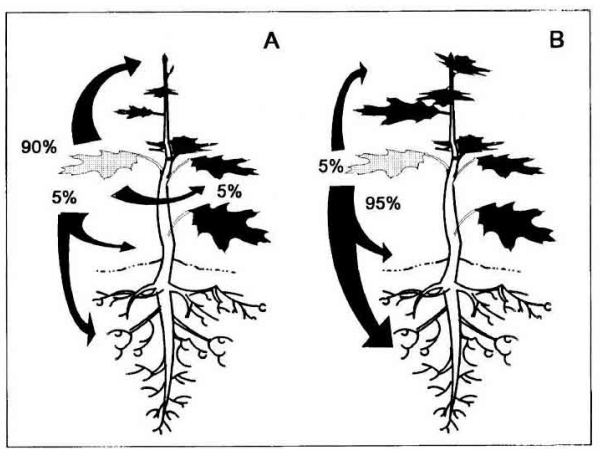

Fig 1. Upward and downward transport of ${ }^{14} \mathrm{C}$ photosynthate from first-fiush leaves of northern red oak. Percentage values indicate within plant allocation of ${ }^{14} \mathrm{C} 48 \mathrm{~h}$ after photosynthetic exposure to ${ }^{14} \mathrm{CO}_{2}$. A. Representative plant at 2-leaf linear. B. Representative plant at 2-lag (from Dickson 1991b). of different oak species and their response to water and other environmental stresses, how could such information be used to improve oak regeneration and subsequent stand growth? Nursery production of highquality seedlings capable of acceptable survival and rapid growth after planting is possible with a few improved management techniques. Seed selection from superior stands or trees, mulching, optimum nursery-bed seed spacing, fertilization and irrigation regimes could significantly increase seedling quality. Such seedlings, planted in stands manipulated to favor oak growth, should survive and grow to be a significant component of future stands (Crow, 1988; Teclaw and Isebrands, 1993; Johnson, 1994). With current management practices, many oak stands in the United States will not maintain adequate numbers of oak after harvest (Crow, 1988; Abrams, 1992). This oak regeneration problem is widespread. Most universal prescriptions developed in one region have failed when used in different parts of the country because each region has its own distinct set of problems associated with oak regeneration. Regional, local and perhaps site-specific alternatives are needed (Teclaw and Isebrands, 1993). Biological and ecological information concerning seedling growth and response to water stress or other environmental stresses could be combined with information on regional climate and site-specific microclimate to design scientifically based silvicultural management systems.

Each tree species has a different strategy or inherent response to the many stresses encountered in its ecological community (Kolb et al, 1990). In addition, response to short-term stress is often quite different from response to long-term stress, and trees have the ability to acclimate to stress over time (Hinckley et al, 1978b, 1991). Considerable genetic variability exists within our most important commercial oak species (Kolb and Steiner, 1989; Kriebel, 1993), and this 
genetic potential could be exploited to select genotypes more suitable for specific sites. Such genetic differentiation has taken place in natural stands (Kubiske and Abrams, 1992; Sala and Tenhunen, 1994) and in introduced populations (Daubree and Kremer, 1993). In addition, there are empirical observations about a large number of less well known oak species and hybrids (Sternberg, 1990). This empirical information could provide insight concerning the growth of these species or genotypes, and site interactions. Northern red oak is a fast growing, highly desirable, commercial and landscape species, but it produces its best growth only on the best mesic sites. Other species are better adapted to wet sites ( $Q$ shumardii, $Q$ nuttallii, $Q$ phellos or $Q$ palustris), to calcarious sites ( $Q$ imbricaria, $Q$ alba, $Q$ muehlenbergii) and to xeric sites ( $Q$ velutina, $Q$ petraea, $Q$ macrocarpa). Given the large number of species and hybrids available, we believe more attention should be given to the introduction and testing of these less conventional species or hybrids in both forestry and urban landscape settings. Why not take advantage of the great potential found within the genus and within each species to improve production on the best sites and to reforest problem sites?

Oak hybrids have great potential to combine the best qualities of both species to improve growth or drought tolerance. The greatest use of oak hybrids is in landscape and horticultural plantings (Sternberg, 1990). Unfortunately, the use of genetically improved or hybrid stock by silvicultural practitioners is not promising (Steiner, 1993). Hybridization among the red oaks (Erythrobalanus) and among the white oaks (Lepidobalanus) is common (Jensen et al, 1993), and many natural and artificial hybrids are available or could be produced that tolerate wet or dry sites and acid or calcareous soils. In addition, hybrids may exhibit hybrid vigor with increased growth rates (Sternberg, 1990). Hybrids have the potential to produce strong adaptable plants for silvicultural and horticultural applications, if we can overcome our conservative approaches and think like long-term agricultural crop breeders. With appropriate seedling quality, genetic selection and stand management, it should be possible to take advantage of the drought resistance and xeric traits of oaks in forest management.

\section{CONCLUSION}

There is no common oak strategy for response to moisture stress. Deep rooting, adaptive leaf morphology, changes in osmotic potential, control of stomatal conductance, drought-resistant energy transfer, drought-resistant carbon fixation-enzyme systems and conservative growth and carbon allocation patterns are all used in varying degrees by different oak species and different ecotypes within species.

Stomatal gas exchange is carefully controlled in most oak species. Oaks, when compared to other associated tree species, maintain some degree of stomatal conductance with increasing water stress. If compietely closed by severe water stress, stomates will rapidly reopen when the stress is removed. Such stomatal control leads to increased water-use efficiency and maintains some carbon fixation during drought episodes.

Nonstomatal responses are quite resistant to water stress in oaks. Photosystem II activities of light energy conversion, electron transport and reductant production are not affected by water stress except under severe drought conditions and high temperatures with no $\mathrm{CO}_{2}$ fixation. The enzyme systems of the dark reactions of carbon fixation also are quite resistant to moisture stress. However, some systems such as the regeneration of ribulose-1,5-bisphosphate may be sensitive to water stress and limit overall carbon fixation. 
Carbon allocation patterns are predictable and dependent on the particular stage of the flush cycle. Carbon flow between starch and sucrose may change during water stress and more carbohydrate may be retained in leaves. However, the major impact of water stress is on leaf development. Water stress imposed during a flush decreases leaf size and number of leaves, may stop flushing altogether and increases carbon allocation to the root system.

There is currently enough information available concerning ecological characteristics and stress response of many oak species to make significant improvements in management practices. Nursery practices such as seed selection, irrigation and fertilization regimes can be designed to produce high-quality oak seedlings. Silvicultural practices could be designed to take advantage of the physiological information and growth strategies of different oak species. More consideration should be given to exotic species and hybrids that are inherently adapted to either highly productive or difficult sites.

\section{REFERENCES}

Abrams MD (1990) Adaptations and responses to drought in Quercus species of North America. Tree Physiol 7, 227-238

Abrams MD (1992) Fire and the development of oak forests. Bioscience 42, 346-353

Abrams MD, Knapp AK (1986) Seasonal water relations of three gallery forest hardwood species in northeast Kansas. For Sci 32, 687-696

Abrams MD, Kubiske ME (1990) Leaf structural characteristics of 31 hardwood and conifer tree species in central Wisconsin: influence of light regime and shade-tolerance rank. For Ecol Manage 31, 245-253

Abrams MD, Schultz JC, Kleiner KW (1990) Ecophysiological responses in mesic versus xeric hardwood species to an early-season drought in central Pennsylvania. For Sci 36, 970-981

Abrams MD, Kubiske ME, Mostoller SA (1994) Relating wet and dry year ecophysiology to leaf structure in contrasting temperate tree species. Ecology 75 , 123-133
Alvin R. Hewett EW, Saunders PF (1976) Seasonal variation in hormone content of willow. I. Changes in abscisic acid content and cytokinin activity in the xylem sap. Plant Physio/57, 474-476

Ashton PMS, Berlyn GP (1994) A comparison of leaf physiology and anatomy of Quercus (section Erythrobalanus - Fagaceae) species in different light environments. Am J Bot 81, 589-597

Bahari ZA, Pallardy SG, Parker WC (1985) Photosynthesis, water relations, and drought adaptations in six woody species of oak-hickory forests in central Missouri. For Sci 31, 557-569

Ball RA, Oosterhuis DM, Mauromoustakos A (1994) Growth dynamics of the cotton plant during waterdeficit stress. Agron J 86, 788-795

Berg EE, Hamrick JL (1993) Regional genetic variation in turkey oak, Quercus laevis. Can J For Res 23, 1270-1274

Black RA, Richards JH, Manwaring JH (1994) Nutrient uptake from enriched soil microsites by three great basin perennials. Ecology 75, 110-122

Borchert R (1991) Growth periodicity and dormancy. In: Physiology of Trees (AS Raghavendra, ed), John Wiley \& Sons, Inc, New York, 221-245

Bragg WK, Knapp AK, Briggs JM (1993) Comparative water relations of seedlings and adult Quercus species during gallery forest expansion in tallgrass prairie. For Ecol Manage 56, 29-41

Bréda N, Cochard H, Dreyer E, Granier A (1993) Water transfer in a mature oak stand (Quercus petraea): seasonal evaluation and effects of a severe drought. Can J For Res 23, 1136-1143

Callaway RM (1990) Effects of soil water distribution on the lateral root development of three species of California oaks. Am J Bot 77, 1469-1475

Chapin FS III, Schulze ED, Mooney HA (1990) The ecology and economics of storage in plants. Ann Rev Ecol Syst 21, 423-447

Chaves MM (1991) Effects of water deficits on carbon assimilation. J Exp Bot 42, 1-16

Clary WP, Tiedemann AR (1986) Distribution of biomass within small tree and shrub form Quercus gambelii stands. For Sci 32, 234-242

Crow TR (1988) Reproductive mode and mechanisms for self-replacement of northern red oak (Quercus rubra) - a review. For Sci 34, 19-40

Daie J (1988) Mechanism of drought-induced alterations in assimilate partitioning and transport in crops. $C R C$ Crit Rev Plant Sci 7, 117-137

Daubree JB, Kremer A (1993) Genetic and phenological differentiation between introduced and natural populations of Quercus rubra L. Ann Sci For 50 (Suppl 1), $271 \mathrm{~s}-280 \mathrm{~s}$

Davies WJ, Zhang J (1991) Root signals and the regulation of growth and development of plants in dry- 
ing soil. Ann Rev Plant Physiol Plant Mol Biol 42, 55-76

Davies WJ. Tardieu F, Trejo CL (1994) How do chemical signals work in plants that grow in drying soil? Plant Physiol 104, 309-314

Deng X, Joly RJ, Hahn DT (1990) The influence of plant water deficit on distribution of ${ }^{14} \mathrm{C}$-labelled assimilates in cacao seedlings. Ann Bot 66, 211-217

Dickson RE (1991a) Assimilate distribution and storage. In: Physiology of Trees (AS Raghavendra, ed), John Wiley \& Sons, Inc, New York, 51-85

Dickson RE (1991b) Episodic growth and carbon physiology in northern red oak. In: The Oak Resource in the Upper Midwest, Implications for Management (SB Laursen, JF DeBoe, eds), Pub No NR-BU-5663S MN Ext Serv, Univ MN, St Paul, MN, 117-124

Dickson RE (1994) Height growth and episodic flushing in northern red oak. In: Biology and Silviculture of Northern Red Oak in the North Central Region: A Synopsis (JG Isebrands, RE Dickson, eds), USDA, For Serv, St Paul, MN, Gen Tech Rep NC-173, 1-9

Dickson RE, Isebrands JG, Tomlinson PT (1990) Distribution and metabolism of current photosynthate by single-flush northern red oak seedlings. Tree Physiol 7, 65-77

Ehleringer JR, Dawson TE (1992) Water uptake by plants: perspectives from stable isotope composition. Plant Cell Environ 15, 1073-1082

Eissenstat DM, Caldwell MM (1988a) Competitive ability is linked to rates of water extraction-a field study of two aridland tussock grasses. Oecologia 75, 1-7

Eissenstat DM, Caldwell MM (1988b) Seasonal timing of root growth in favorable microsites. Ecology 69, 870873

Epron D, Dreyer E (1990) Stomatal and non-stomatal limitations of photosynthesis by leaf water deficits in three oak species: a comparison of gas exchange and chlorophyll a fluorescence data. Ann Sci For $47,435-450$

Epron D, Dreyer E (1993a) Long-term effects of drought on photosynthesis of adult oak trees (Quercus petraea (Matt) Liebl and Quercus robur $\mathrm{L}$ ) in a natural stand. New Phytol 125, 381-389

Epron D, Dreyer E (1993b) Photosynthesis of oak leaves under water stress: maintenance of high photochemical efficiency of photosystem II and non uniform $\mathrm{CO}_{2}$ assimilation. Tree Physiol 13, 107-117

Epron D, Dreyer E, Breda N (1992) Photosynthesis of oak trees [Quercus petraea (Matt) Liebl] during drought under field conditions: diurnal course of net $\mathrm{CO}_{2}$ assimilation and photochemical efficiency of photosystem II. Plant Cell Environ 15, 809-820

Epron D, Dreyer E, Aussenac G (1993) A comparison of photosynthetic responses to water stress in seedlings from 3 oak species: Quercus petraea (Matt) Liebl, $Q$ rubra L, and Q cerris L. Ann Sci For 50 (Suppl 1), $48 \mathrm{~s}-60 \mathrm{~s}$
Epron D, Godard D, Cornic G, Gentry B (1995) Limitation of net $\mathrm{CO}_{2}$ assimilation rate by internal resistance to $\mathrm{CO}_{2}$ transfer in the leaves of two tree species (Fagus sylvatica $\mathrm{L}$ and Castenea sativa Mill). Plant Cell Environ 18, 43-51

Farquhar, GD, Sharkey TD (1982) Stomatal conductance and photosynthesis. Ann Rev Plant Physiol 33, 317-345

Farrar JF et al (1993) Sink strength: what is it and how do we measure it? A round table discussion. Plant Cell Environ 16, 1015-1046

Fitter $\mathrm{AH}$ (1986) The topology and geometry of plant root systems: influence of watering rate on root system topology in Trifolium pratense. Ann Bot 58, 91-101

Gimenez C, Mitchell VJ, Lawlor DW (1992) Regulation of photosynthetic rate of two sunflower hybrids under water stress. Plant Physiol 98, 516-524

Gollan T, Davies WJ, Schurr U, Zhang J (1989) Control of gas exchange: evidence for root-shoot communication on drying soil. Ann Sci For 46 (Suppl), $393 \mathrm{~s}-400 \mathrm{~s}$

Gordon DR, Welker JM, Menke JW, Rice KJ (1989) Competition for soil water between annual plants and blue oak (Quercus douglasii) seedlings. Oecologia $79,533-541$

Gower ST, Isebrands JG, Sheriff DW (1995) Carbon allocation and accumulation in conifers. In: Resource Physiology of Conifers: Acquisition, Allocation, and Utilization (WK Smith, TM Hinckley, eds), Academic Press, New York, 217-254

Gunasekera D, Berkowitz GA (1993) Use of transgenic plants with ribulose-1,5-bisphosphate carboxylase/oxygenase antisense DNA to evaluate the rate limitation of photosynthesis under water stress. Plant Physiol 103, 629-635

Hall MH, Sheaffer CC, Heichel GH (1988) Partitioning and mobilization of photoassimilate in alfalfa subjected to water deficits. Crop Sci 28, 964-969

Harrington MG (1985) The effects of spring, summer, and fall burning on Gambel oak in southwestern ponderosa pine stands. For Sci 31, 156-163

Hewett EW, Wareing PF (1973) Cytokinins in Populus $x$ robusta: changes during chilling and bud burst. Physiol Plant 28, 393-399

Hinckley TM, Aslin RG, Aubuchon RR, Metcalf $C L$, Roberts JE (1978a) Leaf conductance and photosynthesis in four species of the oak-hickory forest type. For Sci 24, 73-84

Hinckley TM, Lassoie JP, Running SW (1978b) Temporal and spatial variation in the water status of forest trees. For Sci Monogr 20

Hinckley TM, Richter H, Schulte PJ (1991) Water relations. In: Physiology of Trees (AS Raghavendra, ed), John Wiley \& Sons, Inc, New York, 137-162

Hsiao TC (1973) Plant responses to water stress. Ann Rev Plant Physiol 24, 519-570 
Isebrands JG, Tomlinson PT, Dickson RE (1994) Carbon fixation and allocation in northern red oak. In: Biology and Silviculture of Northern Red Oak in the North Central Region: A Synopsis (JG Isebrands, RE Dickson, eds), USDA, For Serv, Saint Paul, MN Gen Tech Rep NC- 173, 21-31

Jackson MB (1994) Root-to-shoot communication in flooded plants: involvement of abscisic acid, ethylene, and 1-aminocyclopropane-1-carboxylic acid. Agron J 86, 775-782

Jensen RJ, Hokanson SC, Isebrands JG, Hancock JF (1993) Morphometric variation in oaks of the Apostle Islands in Wisconsin: evidence of hybridization between Quercus rubra and $Q$ ellipsoidalis (Fagaceae). Am J Bot 80, 1358-1366

Johnson PS (1990) Quercus macrocarpa Michx bur oak. In: Silvics of North America. 2. Hardwoods (RM Burns, BH Honkala, eds), USDA, For Serv, Washington, DC, Agric Handbook 654, 686-692

Johnson PS (1994) The silviculture of northern red oak. In: Biology and Silviculture of Northern Red Oak in the North Central Region: A Synopsis (JG Isebrands, RE Dickson, eds), USDA, For Serv, St Paul, MN, Gen Tech Rep NC-173, 33-68

Joly RJ, Hahn DT (1989) An empirical model for leaf expansion in cacao in relation to plant water deficit. Ann Bot 64, 1-8

Jones HG (1985) Partitioning stomatal and non-stomatal limitations to photosynthesis. Plant Cell Environ $8,95-104$

Kelly GJ, Latzko E (1991) Carbon metabolism: on regulation at the cellular level and at the whole plant level, and some considerations concerning the interactions of these regulatory events with the increasing level of atmospheric $\mathrm{CO}_{2}$. Prog Bot 52, 97-121

Khali AAM, Grace J (1993) Does xylem sap ABA control the stomatal behavior of water-stressed sycamore (Acer pseudoplatamus L) seedlings? J Exp Bot 44, 1127-1134

Kicheva MI, Tsonev TD, Popova P (1994) Stomatal and nonstomatal limitations to photosynthesis in two wheat cultivars subjected to water stress. Photosynthetica 30, 107-116

Kleiner KW, Abrams MD, Schultz JC (1992) The impact of water and nutrient deficiencies on the growth, gas exchange and water relations of red oak and chestnut oak. Tree Physiol 11, 271-287

Kleinschmit $\mathrm{J}$ (1993) Intraspecific variation of growth and adaptive traits in European oak species. Ann Sci For 50 (Suppl 1), 166s-185s

Kloeppel BD, Abrams MD, Kubiske ME (1993) Seasonal ecophysiology and leaf morphology of four successional Pennsylvania barrens species in open versus understory environments. Can J For Res 23, 181-189

Kolb TE, Steiner KC (1989) Genetic variation among and within single-tree progenies of northern red oak. For Sci 35, 251-256
Kolb TE, Steiner KC, McCormick LH, Bowersox TW (1990) Growth response of northern red-oak and yellow-poplar seedlings to light, soil moisture and nutrients in relation to ecological strategy. For Ecol Manage 38, 65-78

Kozlowski TT (1982a) Water supply and tree growth. I. Water deficits. For Abs 43, 57-95

Kozlowski TT (1982b) Water supply and tree growth. II. Flooding. For $A b s$ 43, 145-161

Kriebel HB (1993) Intraspecific variation of growth and adaptive traits in North American oak species. Ann SciFor 50 (Suppl 1), 153s-165s

Kriebel HB, Bagley WT, Deneke FJ, Funsch RW, Roth P, Jokela JJ, Merritt C, Wright JW, Williams RD (1976) Geographic variation in Quercus rubra in north central United States plantations. Silvae Genet 25, 118-122

Kubiske ME, Abrams MD (1992) Photosynthesis, water relations, and leaf morphology of xeric versus mesic Quercus rubra ecotypes in central Pennsylvania in relation to moisture stress. Can J For Res 22, 14021407

Kubiske ME, Abrams MD (1993) Stomatal and nonstomatal limitations of photosynthesis in 19 temperate tree species on contrasting sites during wet and dry years. Plant Cell Environ 16, 1123-1129

Kuhns MR, Gjerstad DH (1988) Photosynthate allocation in loblolly pine (Pinus taeda) seedlings as affected by moisture stress. Can J For Res 18, 285-291

Kuhns MR, Stroup WW, Gebre GM (1993) Dehydration tolerance of five bur oak (Quercus macrocarpa) seed sources from Texas, Nebraska, Minnesota, and New York. Can J For Res 23, 387-393

Levy G, Becker M, Duhamel D (1992) A comparison of the ecology of pedunculate and sessile oaks: radial growth in the central and northwest of France. For Ecol Manage 55, 51-63

Little EL Jr (1979) Checklist of United States trees (native and naturalized). USDA, For Serv, Washington, DC, Agric Handbook 541

Matsuda K, McBride JR, Kimura M (1989) Seedling growth form of oaks. Ann Bot 64, 439-446

Metcalfe JC, Davies WJ. Pereira JS (1989) Effects of water deficit on leaf growth and initiation in fastgrowing tree species, Ann Sci For 46 (Suppl), 366s$368 \mathrm{~s}$

Morgan JM (1984) Osmoregulation and water stress in higher plants. Ann Rev Plant Physiol 35, 299 319

Mozes R, Altman A (1977) Characteristics of root-toshoot transport of cytokinin 6-benzylaminopurine in intact seedlings of Citrus aurantiun. Physiol Plant 39, 225-232

Ni BR, Pallardy SG (1992) Stomatal and nonstomatal limitations to net photosynthesis in seedlings of woody angiosperms. Plant Physiol 99, 1502-1508 
Nixon KC (1993) Infrageneric classification of Quercus (Fagaceae) and typification of sectional names. Ann Sci For 50 (Suppl 1), 25s-34s

Olsson T, Leverenz JW (1994) Non-uniform stomatal closure and the apparent convexity of the photosynthetic photon flux density response curve. Plant Cell Environ 17, 701-710

Ortiz-Lopez A, Ort DR, Boyer JS (1991) Photophosphorylation in attached leaves of Helianthus annuus at low water potentials. Plant Physiol 96, 1018-1025

Outlaw WH Jr (1983) Current concepts on the role of potassium in stomatal movements. Physiol Plant 59 , 302-311

Pallardy SG, Rhoads JL (1993) Morphological adaptations to drought in seedlings of deciduous angiosperms. Can J For Res 23, 1766-1774

Raschke K (1975) Stomatal action. Ann Rev Plant Physio/ $26,309-340$

Raschke K, Hedrich R, Reckmann U, Schroeder JI (1988) Exploring biophysical and biochemical components of the osmotic motor that drives stomatal movement: a review. Bonat Acta 101, 283-294

Rushton BS (1993) Natural hybridization within the genus Quercus L. Ann Sci For 50 (Suppl 1), 73s-90s

Sala A, Tenhunen JD (1994) Site-specific water relations and stomatal response of Quercus ilex in a Mediterranean watershed. Tree Physiol 14, 601617

Sharkey TD (1990) Water stress effects on photosynthesis. Photosynthetica 24, 651

Smit BA, Neuman DS, Stachowiak ML (1990) Root hypoxia reduces leaf growth. Plant Physio/ 92, 10211028
Steiner KC (1993) Genetic improvement of oaks in North America. Ann Sci For 50 (Suppl 1), 359s-367s

Sternberg G (1990) Sturdy as an oak. Am Nurseryman $172,33-45$

Stitt M (1991) Rising $\mathrm{CO}_{2}$ levels and their potential significance for carbon flow in photosynthetic cells. Plant Cell Environ 14, 741-762

Stitt M, Quick WP (1989) Photosynthetic carbon partitioning: its regulation and possibilities for manipulation. Physiol Plant 77, 633-641

Stitt M, Schulze D (1994) Does Rubisco control the rate of photosynthesis and plant growth? An exercise in molecular ecophysiology. Plant Cell Environ 17, 465487

Stone EL, Kalisz PJ (1991) On the maximum extent of tree roots. For Ecol Manage 46, 59-102

Teclaw RM, Isebrands JG (1993) An artificial regeneration system for establishing northern red oak on dry-mesic sites in the Lake States, USA. Ann Sci For 50, 543-552

Tyree MT, Ewers FW (1991) Tansley review no 34. The hydraulic architecture of trees and other woody plants. New Phytol 119, 345-360

Vivin P. Aussenac G, Levy G (1993) Differences in drought resistance among 3 deciduous oak species grown in large boxes. Ann Sci For 50, 221-233

Weber JA, Gates DM (1990) Gas exchange in Quercus rubra (northern red oak) during a drought: analysis of relations among photosynthesis, transpiration, and leaf conductance. Tree Physiol 7, 215-225

Wuenscher JE, Kozlowski TT (1971) Relationship of gas-exchange resistance to tree-seedling ecology. Ecology 52, 1016-1023 